\title{
The Role of $\mathrm{C3}$ in Mediating Binding and Ingestion of Group B Streptococcus Serotype III by Murine Macrophages ${ }^{1}$
}

\author{
GARY J. NOEL, STEVEN L. KATZ, AND PAUL J. EDELSON \\ Department of Pediatrics, Division of Pediatric Infectious Diseases and Immunology, Cornell University Medical \\ College, New York, New York 10021
}

\begin{abstract}
To understand how complement effects phagocytosis of type III group B streptococcus, we assessed the specific role of $\mathrm{C} 3$ in mediating binding and ingestion of these bacteria by macrophages. Phagocytosis of bacteria by resident mouse peritoneal macrophages was measured under conditions in which $\mathrm{C} 3$ deposition on bacteria was inhibited or after blockade of C3-ligands or of complement receptor type three (CR3) with specific antibodies. $\mathrm{C} 3$ depletion, incubation with $\mathrm{F}\left(\mathrm{ab}^{\prime}\right) 2$ fragments of antibody to $\mathrm{C3}$, or blockade of CR3 completely inhibited the binding of bacteria that was seen in the presence of nonimmune serum. Immune serum increased the number of associated organisms 6-fold compared to that seen with nonimmune serum. With this serum, $82 \%$ of organisms were ingested. $\mathrm{C} 3$ depletion or CR3 blockage had a modest effect, but this interaction could be ablated completely only after $\mathrm{Fc}$ receptors were blocked. Using varied concentrations of an IgG2a MAb against type III capsular antigen, it was possible to show that small amounts of antibody incapable of mediating bacterial binding by itself directed an interaction that also depended upon C3. Phagocytosis of group B streptococci by macrophages in the presence of little or no antibody requires complement and $\mathrm{C} 3$ opsonization specifically. C3-dependent binding may be important in determining mononuclear phagocyte-dependent clearance of these pathogens from blood, particularly in patients with little or no type-specific serum antibody. (Pediatr Res 30: 118-123, 1991)
\end{abstract}

Abbreviations

CR3, complement receptor type 3

$\mathrm{Ni}$-S, nonimmune serum

Im-S, immune serum

CoVF, cobra venom factor

PB, phagocytosis buffer

i.p., intraperitoneal

HBSS, Hanks' balanced salt solution

Serum complement proteins play a critical role in host defense against a variety of microbes (1). Recent work examining this

Received November 9, 1990; accepted February 26, 1991.

Correspondence: Gary J. Noel, M.D., N-834, The New York Hospital-Cornell Medical Center, 525 East 68th Street, New York, NY 10021.

Supported in part by U.S. Public Health Grant AI19888-041 and BRS grant support 2S07 RR05398-27. G.J.N. is a recipient of a Clinical Associate Physician Award and is supported in part by U.S. Public Health Grants 1M01 RR060201-01 and AI30063-01.

'Presented in part by S.L.K. as his Medical Research Thesis at Cornell University Medical College, May 1989. role with encapsulated pneumococci and Haemophilus influen$z a e$ has underscored that complement-mediated phagocytosis is important in defending against these pathogens (2-6). These studies are consistent with the hypothesis that clearance of complement-opsonized bacteria from the circulation by mononuclear phagocytes composing the reticuloendothelial system is essential in defending against bacteremia and in preventing disseminated infection. This complement-mediated host defense is likely to be particularly important in the nonimmune patient who must clear bacteria from the blood in the presence of little or no antibacterial antibody.

Complement opsonization is generally considered to be important in defending against group B streptococcal infection. In vitro studies measuring neutrophil chemiluminescence or neutrophil-directed bacterial killing suggest that complement enhances antibody-mediated phagocytosis (7-15). Although the newborn's unique susceptibility for disseminated group B streptococcal infection has been associated with a relative complement deficiency $(16,17)$, the precise role for complement in defending the newborn against group B streptococci is not known. Based on work with other encapsulated bacteria, however, it is likely that complement serves as an important opsonin, mediating phagocyte-bacteria interactions in the presence and in the absence of type-specific antibody.

In the work presented in this report, we examined the role of complement in determining the binding and ingestion of type III group B streptococci by resident peritoneal mouse macrophages. We characterized the degree of binding and ingestion in fresh serum and examined the specific roles of $\mathrm{C} 3$ and CR 3 in this interaction. Because the newborn is likely to depend on host defense mechanisms that occur in the presence of little or no type-specific antibody $(18,19)$, this study was additionally directed at examining complement's role in phagocytosis that occurs in Ni-S and serum containing varied concentrations of type-specific antibody. Macrophages were studied because it is likely that interaction of encapsulated bacteria with mononuclear phagocytes determines clearance of these pathogens from the bloodstream $(14,20,21)$.

\section{MATERIALS AND METHODS}

Organisms. An isolate of group B streptococcus serotype III was provided by Dr. Jose I. Santos (Hospital Infantil de Mexico, Mexico, Départemento Fédéral). This isolate has been previously characterized and studied (22). Streptococcal group of this isolate was confirmed before testing using FITC conjugated antibody to group B antigen (Difco Laboratories Inc., Detroit, MI). The $\mathrm{LD}_{50}$ of this strain after i.p. inoculation in 5-d-old infant rats was $5 \times$ $10^{3}$ colony forming units. Organisms were stored at $-70^{\circ} \mathrm{C}$ in skim milk broth (Difco). Shavings of frozen broth were inoculated onto trypticase soy agar with 5\% sheep blood (BBL Microbiology Systems, Cockeysville, MD) and incubated overnight at 
$37^{\circ} \mathrm{C}$. Colonies were scraped from plates and incubated for $4-5$ $\mathrm{h}$ at $37^{\circ} \mathrm{C}$ in $1 \mathrm{~mL}$ of Todd-Hewitt Broth (Difco) containing 0.02 $\mathrm{mCi}$ of tritiated thymidine (sp act $20 \mathrm{Ci} / \mathrm{mmol}$; New England Nuclear, Boston, MA). Labeled organisms were washed three times in PB [HBSS (Gibco, Grand Island, NY) containing $0.2 \%$ glucose, $0.02 \%$ gelatin]. Label uptake was determined for each experiment and ranged between 400 and 2100 colony forming units/cpm.

Serum. Serum was obtained from CDF-1 mice as previously described (6). Ni-S was obtained from adult CDF-1 mice (20-25 g; Charles River Breeding Laboratories, Wilmington, MA). Im-S was obtained from adult mice 2 wk after a second i.p. inoculation of group B streptococcus type III. Serum was obtained from CoVF (Cordis Laboratories, Miami, FL)-treated, nonimmune mice $20 \mathrm{~h}$ after a 5-U CoVF i.p. inoculation. Serum obtained from these animals had no detectable $\mathrm{C} 3$ fixation titer $(\leq 1: 2)$ and had less than $20 \mathrm{mg} / \mathrm{dL}$ of $\mathrm{C} 3$ as determined by a radial immunodiffusion method (6). Serum was heat-inactivated by incubation for $60 \mathrm{~min}$ at $56^{\circ} \mathrm{C}$. This serum had no functional complement activity as measured by $\mathrm{C} 3$ fixation to rabbit red blood cells (6).

Concentration of serum antibody directed against type III group B streptococcus was determined by a whole organism ELISA similar to that previously described (23). Serum was diluted in PBS (Gibco) containing 0.5\% BSA to yield a final serum concentration of 25 to $0.01 \%$, and was incubated with approximately $10^{9}$ organisms in 1.5-mL Eppendorf polypropylene micro tubes (Sarstedt, Princeton, NJ) at $37^{\circ} \mathrm{C}$ for $30 \mathrm{~min}$. Organisms were washed three times in cold PBS and resuspended in $100 \mu \mathrm{L}$ of a 1:200 dilution of horseradish peroxidase-conjugated goat antibody to mouse IgG and IgM (Jackson laboratories, Bar Harbor, ME) and incubated for $30 \mathrm{~min}$ at $4^{\circ} \mathrm{C}$. Organisms were then washed three times, resuspended in $1 \mathrm{~mL}$ of $0.075 \%$ 3,3'-diaminobenzidine (Sigma Chemical Co., St. Louis, MO) containing $0.03 \% \mathrm{H}_{2} \mathrm{O}_{2}$. The reaction was allowed to proceed for $15 \mathrm{~min}$ before the OD of the supernatant was measured at 460 $\mathrm{nm}$. The ELISA titer was defined as the lowest concentration of serum that gave $\geq 20 \%$ of control values (controls were organisms incubated with buffer alone). Pooled serum from nonimmune animals consistently had titers of $<1: 4$, the highest concentration of serum tested. Pooled serum from immune animals had a titer of 1:1024. Ascites fluid containing MAb SIIIS8C3 (see below) diluted 1:2 in PB had a titer of 1:1024.

$C 3$ deposition on bacteria. Deposition of $\mathrm{C} 3 \mathrm{c}$ on bacteria was assessed by an immunofluorescent assay (6). Organisms (approximately $10^{9}$ ) were incubated with $50 \% \mathrm{Ni}-\mathrm{S}$, Im-S, serum from CoVF-treated mice, heat-inactivated serum, Ni-S with $5 \mathrm{mM}$ EGTA/ $8 \mathrm{mM} \mathrm{Mg}{ }^{++}$, or Ni-S with $5 \mathrm{mM}$ EDTA for $30 \mathrm{~min}$ at $37^{\circ} \mathrm{C}$ in HBSS. After incubation, organisms were washed three times in cold HBSS and then resuspended in $100 \mu \mathrm{L}$ of a $1: 100$ dilution of FITC-conjugated goat antibody to mouse C3c (Cappel, Organon Teknika Corp., West Chester, PA). After a 20-min incubation at $4^{\circ} \mathrm{C}$, organisms were washed in cold HBSS and examined by fluorescent microscopy. $\mathrm{C} 3$ deposition was evident as a ring of fluorescence outlining bacteria. The reagent used recognizes a fragment of $\mathrm{C} 3$ contained in $\mathrm{C} 3 \mathrm{~b}, \mathrm{C} 3 \mathrm{bi}$, and $\mathrm{C} 3 \mathrm{c}$ and therefore does not distinguish among these forms of $\mathrm{C} 3$.

C3 fixation titer was determined as the lowest concentration of serum that resulted in $\mathrm{C} 3$ deposition on type III group $\mathrm{B}$ streptococcus. To assess the ability of antibody to enhance C3 deposition, this titer was determined with nonimmune $\mathrm{Ni}-\mathrm{S}$ both without addition of antibody and in the presence of a 1:100 dilution of ascites fluid containing antibody SIIIS8C3. Approximately $10^{9}$ organisms were incubated for $30 \mathrm{~min}$ at $37^{\circ} \mathrm{C}$ in diluted serum (final concentrations 50 to $1.5 \%$ ) and antibody in a total volume of $100 \mu \mathrm{L}$ containing HBSS. Organisms were washed and immunofluorescently stained as described above.

Radiobinding assay for determining macrophage interaction with group B streptococcus. Resident peritoneal mouse macrophages were harvested from adult CDF-1 mice as described (3).
Monolayers were adhered to glass coverslips placed in the bottom of 24-well Falcon tissue culture plates. The number of cells adherent to coverslips ranged from $8 \times 10^{4}$ to $1.3 \times 10^{5}$. This was determined for each day's experiment by counting cells in each of five representative fields with an inverted microscope and extrapolating to total coverslip surface area.

Binding and ingestion of organisms to macrophages was determined by a radiobinding assay similar to that previously described by us (3). Between $8 \times 10^{6}$ to $2 \times 10^{7}$, radiolabeled organisms were added to macrophage monolayers in the absence or presence of serum or antibody in PB in a total volume of 0.3 $\mathrm{mL}$. After incubation, monolayers were washed four times in PB to remove unbound bacteria. Coverslips were then removed and placed in $3.5 \mathrm{~mL}$ of Aquassure (New England Nuclear) and counted. The number of organisms associated with macrophages was calculated by dividing the number of bacteria associated with each coverslip (counts per coverslip $\times$ colony forming units per count) by the number of macrophages per coverslip. Experiments were done in duplicate and the results from each day's experiment were averaged. Binding directly to coverslips was assessed by measuring counts associated with coverslips incubated with labeled organisms in the absence or presence of serum. Background binding was consistently calculated to be less than 0.4 organisms/macrophage ( $<80$ counts/coverslip).

Glutaraldehyde-fixed, Giemsa-stained monolayers were directly examined using phase contrast microscopy in some experiments and were done in parallel to radiobinding assays. This examination demonstrated that over $98 \%$ of bacteria were associated with macrophages (Fig. 1).

Binding versus ingestion of bacteria. Ingestion of organisms was assessed by methods similar to those used to measure ingestion of $H$. influenzae by macrophages (3). After incubation with bacteria, washed monolayers were fixed in either $100 \%$ methanol or 3.3\% neutral buffered formalin (Sigma Chemical Co.). Fixed monolayers were then serially incubated with a 1:200 dilution of an IgM MAb to type III capsule (SIIIV18C2 ascites fluid, described below) and a 1:100 dilution of FITC-conjugated goat antibody to murine Ig (Tago, Burlingame, CA). Because methanol fixation permits immunofluorescent staining of both internalized and bound bacteria, whereas formalin fixation prevents staining of ingested bacteria (3), the number of ingested organisms was calculated by subtracting the number of immunofluorescently stained bacteria seen associated with formalin-fixed cells from those stained and associated with methanol-fixed cells. Percentage of ingestion was calculated by dividing the number of organisms ingested by the total associated and multiplying by 100.

Antistreptococcal antibodies. MAb to type III group B streptococcal polysaccharide sialated antigen were provided by Dr. David G. Pritchard (University of Alabama at Birmingham) (Table 1). Ascites fluid containing antibody SIIIS8C3 (mouse IgG2a) was used in phagocytosis experiments. This antibody has been demonstrated to be protective in a mouse model for group B streptococcal infection (24). Ascites fluid containing IgM monoclonal SIIIV18C2 was used to immunofluorescently stain bacteria.

Antibodies to macrophage surface proteins and murine C3. As previously described (3), MAb directed against murine macrophage surface proteins were used to inhibit receptor-mediated binding of opsonized particles to macrophages (Table 1). Antibody M1/70 (25), was incubated with macrophage monolayers for $20 \mathrm{~min}$ before addition of bacteria. The concentration of antibody $\mathrm{M} 1 / 70$ used has been shown to inhibit specifically $\mathrm{C} 3 \mathrm{bi}$ opsonized particle binding to monolayers while inhibiting less than $10 \%$ of $\operatorname{IgG}$ or $\mathrm{C} 3 \mathrm{~b}$ opsonized particle binding $(3,25)$. Purified MAb 2.4G2 (provided by Dr. Ellen Pure, Rockefeller University, New York, NY) was used to block Fc-mediated binding to macrophages as previously described in our laboratory (3). Incubation of monolayers with $10 \mu \mathrm{g} /$ well of this reagent completely inhibited IgG-coated sheep red cell binding but had 

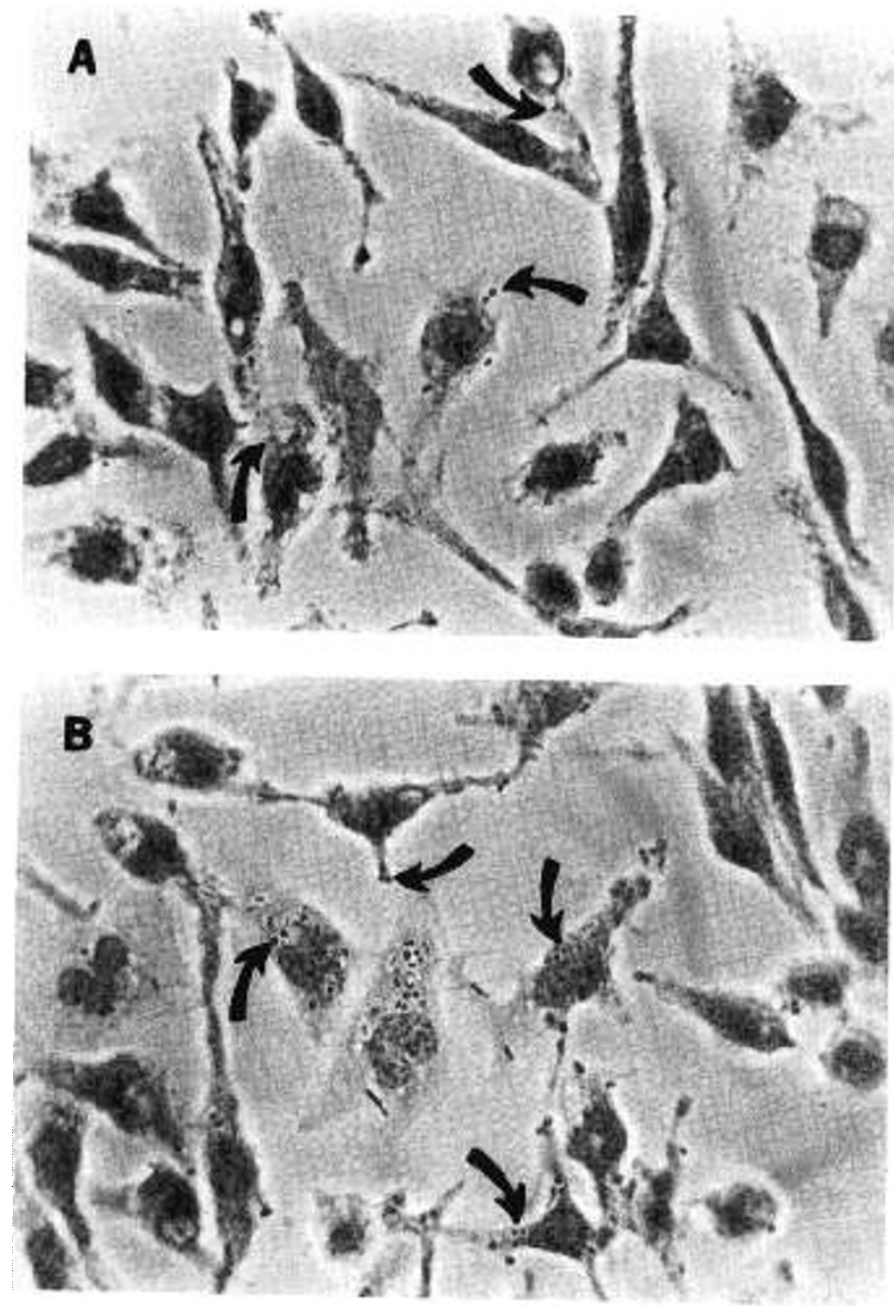

Fig. 1. Association of type III group $\mathrm{B}$ streptococci with resident peritoneal mouse macrophages in the presence of $8 \% \mathrm{Ni}-\mathrm{S}(A)$ and $8 \%$ Im-S $(B)$. Monolayers were fixed in $2 \%$ glutaraldehyde and Giemsa stained. Both sera increased association of organisms with monolayers above that seen with buffer alone. Im-S increased association nearly 6fold compared to that measured with Ni-S. Examples of associated organisms are identified by arrows.

Table 1. MAb used in this study

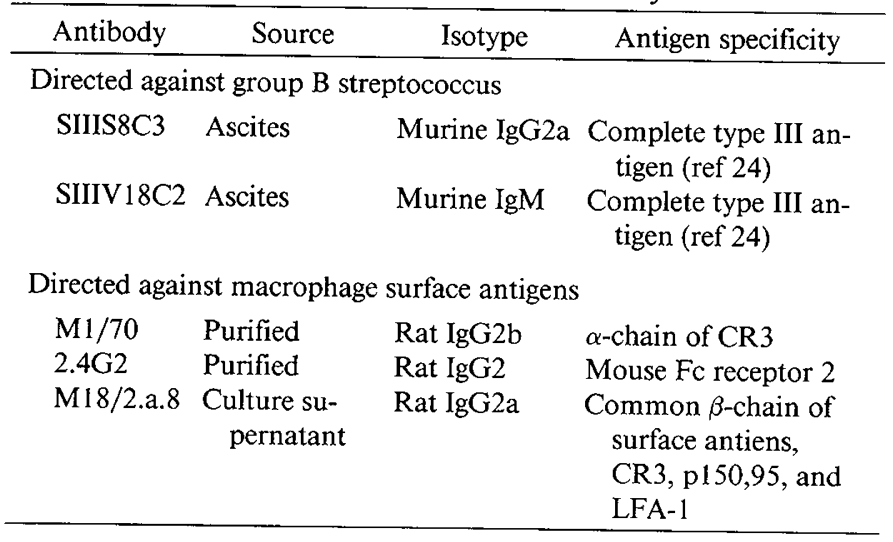

no effect on C3-opsonized red cell binding (3). The effect of an $\mathrm{MAb}$ directed against an epitope of a macrophage surface protein that is not involved in binding of either antibody or complement was assessed using MAb M18/2.a.8. This IgG2a rat antibody is directed against the $\beta$-chain of leukocyte antigens p150,95, CR3, and LFA-1. Monolayers were incubated with this reagent before addition of bacteria as previously described and had no effect on either antibody-coated or complement-coated red cell binding (3).

$\mathrm{F}\left(a b^{\prime}\right) 2$ fragments of goat antibody to mouse C3 (Cappel) were used to assess the role of bacterial bound $\mathrm{C} 3$ in determining the interaction of bacteria with macrophages. This antibody recognizes $\mathrm{C} 3 \mathrm{~b}, \mathrm{C} 3 \mathrm{bi}$, and $\mathrm{C} 3 \mathrm{c}$ and specifically inhibited $\mathrm{C} 3$-opsonized red cell binding but did not affect IgG-opsonized red cell binding when used at a concentration of $500 \mu \mathrm{g} / \mathrm{mL}$ (3).

The effect of macrophage receptor or ligand blockade on the interaction of bacteria with macrophages was expressed as an inhibition index: 1 - (number of organisms in presence of reagent/number of organisms associated without the reagent). In this manner pooled data measuring the degree of inhibition was normalized before comparison.

Statistical analysis. Differences were compared using $t$ test (between samples) and Wilcoxon's rank sum test (between inhibition indices, and percentage of ingestion/binding) (26).

\section{RESULTS}

Murine C3 Deposition on Group B Streptococcus. Using fluorescent microscopy, $\mathrm{C} 3 \mathrm{c}$ deposition was evident on organisms after incubation in Ni-S, Ni-S with $5 \mathrm{mM}$ EGTA/8 $\mathrm{mM} \mathrm{Mg}^{++}$, and Im-S (results not shown). This deposition was not seen on organisms incubated in heat-inactivated serum, serum from CoVF-treated mice, or Ni-S with 5 mM EDTA. These observations are consistent with the hypothesis that $\mathrm{C} 3$ deposition on type III group B streptococci can occur via the alternative complement pathway (13).

The effect of antibody on C3 deposition was assessed by measuring $\mathrm{C} 3$ fixation titers. Organisms were incubated with MAb SIIIS8C3 (IgG2a) diluted 1:100 and varied concentrations of Ni-S. After incubation C3 fixation was assessed by immunofluorescence and the lowest concentration of serum that resulted in fixation was determined. Ni-S alone had a titer of 1:4. This serum C3 fixation titer increased to $1: 25$ in the presence of antibody. C3 deposition on organisms was not evident after incubation in undiluted ascites fluid alone, indicating that the enhanced deposition seen with antibody-containing ascites was a result of antibody's effect rather than any residual complement activity in this fluid.

Interaction of Group B Streptococci with Macrophages. Binding and ingestion in $\mathrm{Ni}-\mathrm{S}$ and $\mathrm{Im}-\mathrm{S}$. The number of organisms associated with macrophages after a 1 -h incubation with $8 \%$ Ni-S was 7 times greater $(2.2 \pm 0.1)$ than that seen with buffer alone $(0.3 \pm 0.0)$ (Table 2). Furthermore, the association of organisms in $8 \%$ Im-S was approximately 6 times greater than that seen with Ni-S $(14.1 \pm 1.6$ versus $2.2 \pm 0.1)$ (Table 2$)$ and over 40 times greater than that in the absence of serum. Representative fields from these experiments (after a 1-h incubation) are shown in Figure 1. The number of organisms associated with macrophages in the presence of $\mathrm{Ni}-\mathrm{S}$ or Im-S increased gradually and appeared to plateau after $50 \mathrm{~min}$ (Table 2). Subsequent experiments were therefore performed with a 1-h incubation.

Ingestion of bacteria was distinguished from binding alone by examining immunofluorescently stained monolayers fixed in

Table 2. Association of organisms with macrophages incubated for 60 min in absence of serum (buffer alone) and in presence of $8 \% \mathrm{Ni}-\mathrm{S}$ or $8 \% \mathrm{Im}-\mathrm{S}^{*}$

\begin{tabular}{lcccc}
\hline & \multicolumn{4}{c}{ Organisms/macrophages $\pm \mathrm{SD}$} \\
\cline { 2 - 5 } & $10 \mathrm{~min}$ & $30 \mathrm{~min}$ & $50 \mathrm{~min}$ & $60 \mathrm{~min}$ \\
\hline Buffer alone & $0.1 \pm 0.01$ & $\mathrm{ND}$ & $\mathrm{ND}$ & $0.3 \pm 0.0$ \\
$\mathrm{Ni}-\mathrm{S}$ & $0.1 \pm 0.1$ & $0.8 \pm 0.2$ & $1.5 \pm 0.8$ & $2.2 \pm 0.1 \dagger$ \\
$\mathrm{Im}-\mathrm{S}$ & $1.9 \pm 0.7 \dagger$ & $6.5 \pm 1.1$ & $10.3 \pm 1.2$ & $14.1 \pm 1.6 \dagger$ \\
\hline
\end{tabular}

* Results of three experiments. Mean inoculum size was $167 \pm 40$ organisms per macrophage. ND, not determined.

$\dagger$ Difference significant $(p<0.01)$ compared to buffer alone as determined by $t$ test. 
either methanol or formalin (3). Ingestion of organisms after a 1 -h incubation with monolayers in the presence of $8 \% \mathrm{Ni}-\mathrm{S}$ or $8 \% \mathrm{Im}-\mathrm{S}$, or in $8 \%$ ascites fluid containing IgG2a anti-group B streptococcus was assessed. In Ni-S $31 \pm 21 \%(n=3)$ of associated organisms were ingested, in Im-S $82 \pm 14 \%(n=4)$ of organisms were ingested, and in IgG2a $88 \pm 6 \%(n=2)$ of organisms were ingested. Ingestion was significantly greater in Im-S compared with that seen with $\mathrm{Ni}-\mathrm{S}$ ( $p<0.05$ by rank sum).

Role of $C 3$ opsonization. Complement's role in determining macrophage-bacterial interaction was assessed using heat-treated serum or C3-depleted serum from CoVF-treated mice or by specific blockade of bacterial bound $\mathrm{C} 3$ with $\mathrm{F}\left(\mathrm{ab}^{\prime}\right) 2$ fragments of antibody directed against C3. Heat-inactivated Ni-S or C3depleted Ni-S did not mediate binding of organisms to macrophages above levels seen with buffer alone $(0.1 \pm 0.1$ and $0.5 \pm$ 0.3 versus $0.3 \pm 0.0$ ) (Table 3 ). Similarly, $F\left(a^{\prime}\right) 2$ fragments of antibody directed against $\mathrm{C} 3$ reduced the binding seen with fresh $\mathrm{Ni}$-S to background levels $(0.4 \pm 0.3)$. These results indicate that the interaction measured in the presence of $\mathrm{Ni}-\mathrm{S}$ was mediated by $\mathrm{C} 3$.

Similar experiments with $\mathrm{Im}-\mathrm{S}$ showed that heat inactivation or $F\left(a b^{\prime}\right) 2$ fragments to $C 3$ alone reduced the level of binding of group B streptococci to macrophages from $11.3 \pm 3.4$ to $4.2 \pm$ 3.0 and $4.5 \pm 3.5$, respectively (Table 3 ). However, in contrast to results with $\mathrm{Ni}-\mathrm{S}$, the number of organisms associated with macrophages under these conditions still remained well above that seen with buffer alone. Blockade of Fc receptors with MAb $2.4 \mathrm{G} 2$ reduced binding seen in heat-inactivated Im-S to $0.6 \pm$ 0.4 organisms/macrophage, levels that were not distinguishable from background. These results suggested that $\mathrm{C} 3$ enhanced the interaction measured in $\mathrm{Im}-\mathrm{S}$ but that both $\mathrm{C} 3$ and $\mathrm{Fc}$ receptors mediated the interaction seen in this serum.

Role of macrophage CR3. Because $\mathrm{C} 3$ mediated the interaction of group B streptococci with macrophages in the presence of $\mathrm{Ni}$ $\mathrm{S}$ and enhanced the interaction seen with $\mathrm{Im}-\mathrm{S}$, the role of a well-defined $\mathrm{C} 3$ receptor (CR3) in this process was assessed using MAb M1/70 (Fig. 2). The concentration of M1/70 used in experiments was shown to inhibit less than $10 \%$ of IgG-coated sheep red cell binding, but inhibited C3bi-coated red cell binding by greater than $90 \%$. After addition of $\mathrm{Ml} / 70,95 \%$ (inhibition index $=0.95 \pm 0.03, n=5)$ of Ni-S-mediated binding (3.7 \pm 2.8 organisms/macrophage) was inhibited. Although M1/70 is a $\mathrm{MAb}$ that recognizes an epitope on the $\alpha$-chain of CR3, previous work examining human mononuclear phagocytes has demonstrated that M1/70 may, under certain conditions, also inhibit IgG-mediated binding via high-affinity Fc receptors (27). Therefore, the effect of M1/70 on IgG2a-mediated binding of bacteria was also measured (Fig. 3). At levels of binding comparable to that seen with $\mathrm{Ni}-\mathrm{S}$ alone ( $3.9 \pm 0.5$ organisms/macrophage), IgG2a-mediated interaction was inhibited by $55 \%$ (inhibition

Table 3. Effect of heat-inactivated serum, serum from CoVF, $C 3$-depleted mice, or $F\left(a b^{\prime}\right) 2$ fragments of antibody to $C 3$ on association of type III group B streptococci with resident peritoneal macrophages after $1 \mathrm{~h}$ incubation*

\begin{tabular}{lcccc}
\hline & \multicolumn{3}{c}{ Organisms/macrophage $\pm \mathrm{SD}$} \\
\cline { 2 - 5 } & $\begin{array}{c}\text { Fresh } \\
\text { serum } \\
\text { alone }\end{array}$ & $\begin{array}{c}\text { Heat- } \\
\text { inactivated } \\
\text { serum }\end{array}$ & $\begin{array}{c}\text { C3-depleted } \\
\text { serum }\end{array}$ & $\begin{array}{c}\text { Fresh serum } \\
\text { anti-C3 }\left(\mathrm{ab}^{\prime}\right) 2\end{array}$ \\
\hline Nonimmune & $2.8 \pm 1.3$ & $0.1 \pm 0.1 \dagger$ & $0.5 \pm 0.3 \dagger$ & $0.4 \pm 0.3 \dagger$ \\
& $n=9$ & $n=7$ & $n=4$ & $n=4$ \\
Immune & $11.3 \pm 3.4$ & $4.2 \pm 3.0 \dagger$ & $\mathrm{ND}$ & $4.5 \pm 3.5 \dagger$ \\
& $n=12$ & $n=11$ & & $n=6$ \\
\hline
\end{tabular}

* Serum was obtained from nonimmune or immune mice. Inoculum size (organisms:macrophage) ranged from $82: 1$ to $217: 1$. ND, not determined.

$\dagger$ Differences significant $(p<0.01)$ compared to fresh serum of the same type alone as determined by $t$ test.
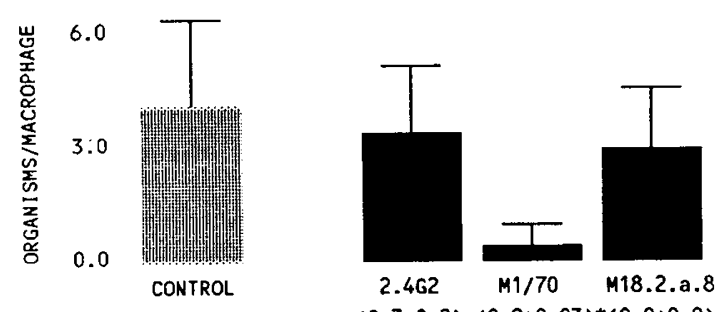

$(0.3+0.2)(0.9 \pm 0.03) *(0.0 \pm 0.0)$

NON-IMMUNE SERUM

Fig. 2. Effect of MAb directed against the $\mathrm{Fc}$ receptor (2.4G2), the CR3 $(M I / 70)$, and the common $\beta$-chain of macrophage surface proteins p150,95, CR3, and LFA-1 (M18/2.a.8) on association of type III group B streptococci with resident peritoneal mouse macrophages in the presence of $8 \% \mathrm{Ni}$-S. The stippled bar indicates association measured with $8 \%$ fresh serum alone (CONTROL) $+\mathrm{SD}(n=10)$. Black bars represent association measured in $8 \%$ fresh serum MAb $+\operatorname{SD}(2.4 G 2, n=4 ; M 11$ $70, n=5 ;$ M18.2.a.8, $n=3)$. Numbers in parentheses are index of inhibition [ 1 - (number of associated organisms in absence of MAb/ number of associated organisms in absence of MAb) \pm SD. Asterisk indicates statistical significance $(p<0.05)$ between inhibition index seen with M1/70 compared to that seen with M18/2.a.8 as determined by Wilcoxon's rank sum.

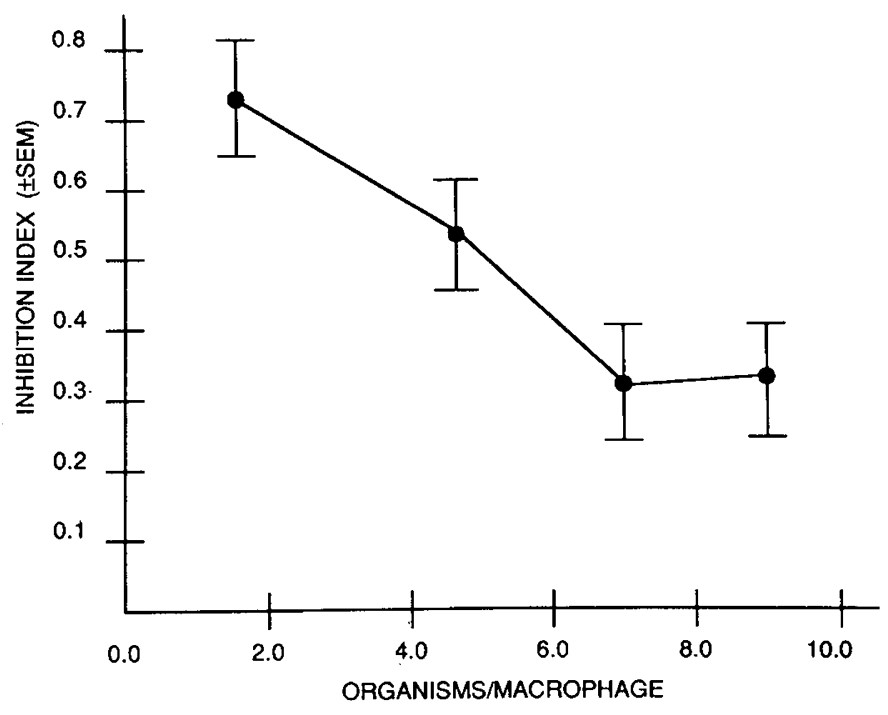

Fig. 3. Effect of MAb M1/70 (antibody to the $\alpha$-chain of CR3) on IgG2a-mediated interaction of type III group B streptococci with murine resident peritoneal macrophages. Points represent the mean inhibition index $( \pm \mathrm{SEM})$ calculated for at least four experiments. Organisms/ macrophage were determined by radiobinding assay and points represent the mean for each set of experiments.

index $=0.55 \pm 0.24, n=4)$. Differences in the degree of inhibition at this level of binding mediated by Ni-S or IgG2a were significantly different $(0.55 \pm 0.24$ versus $0.95 \pm 0.03, p<$ 0.05 , by rank sum). Similar experiments using MAb 2.4G2 at concentrations previously shown to inhibit both high-avidity (IgG2a-specific) and low-avidity (IgG2b, IgG1) Fc receptors (28, 29) showed that $77 \%$ of the $3.9 \pm 0.7$ organisms associated with macrophages in the presence of IgG2a were inhibited by this reagent (inhibition index $=0.77 \pm 0.12, n=5$ ). However, blockade of Fc receptors had little, if any, effect (Fig. 2) on the interaction seen in Ni-S. The complete inhibition of the Ni-Smediated interaction by $\mathrm{M} 1 / 70$ and the inability of $\mathrm{Fc}$ receptor blockade using antibody $2.4 \mathrm{G} 2$ to affect this interaction suggest that the effect of $\mathrm{M} 1 / 70$ blockade on $\mathrm{Ni}-\mathrm{S}$ was due to its inhibition of a CR3-mediated process rather than the partial blockade of $\mathrm{Fc}$ receptor function that has been previously described with M1/70 (26). This interpretation is further supported 
by observations that this interaction depended on the deposition of $\mathrm{C} 3$ on organisms.

In Im-S, CR3 blockade reduced the number of organisms associated with macrophages by approximately $30 \%$ (inhibition index $=0.26 \pm 0.19, n=6$ ). This difference was significant ( $p$ $<0.05$ ) when compared to the effect of control noninhibitory rat IgG antibody M18.2.a.8. Little effect on this interaction was seen with MAb 2.4G2 when used alone (inhibition index $=0.1$ $\pm 0.1, n=5$ ).

Antibody-directed, complement-mediated interactions. To examine the role of $\mathrm{C} 3$ in the presence of varied concentrations of antibody, the interaction of group B streptococci with macrophages was measured in $\mathrm{Ni}-\mathrm{S}$ to which different concentrations of an MAb directed against type III antigen was added (Fig. 4). This approach was taken to maintain a constant concentration of serum complement while varying the concentration of a specific protective antibody (IgG2a SIIIS8C3).

Increasing concentrations of an IgG2a anti-type III MAb alone increased the number of associated organisms (Fig. 4). At the highest concentration of antibody tested ( $8 \%$ ascites fluid, ELISA titer $1: 128)$ an average of 8.5 organisms were associated per macrophage (not shown). Concentrations of antibody in excess of that present in $1.67 \%$ ascites fluid were necessary to detect binding greater than that seen with buffer alone (Fig. 4). The addition of fresh Ni-S increased the number of organisms associated with monolayers above that seen with either antibody or serum alone (Fig. 4). This indicated that, at low concentrations of this IgG2a antibody, complement is required to mediate antibody-dependent interactions. With concentrations of antibody in $1.67 \%$ ascites fluid and serum $(4 \%), 56 \%(56 \pm 27, n=$ 3) of associated organisms were ingested.

To assess the specific role of $\mathrm{C} 3$ in this process, the effect of C3-depleted Ni-S and $F\left(a b^{\prime}\right) 2$ blockade of bacterial bound $\mathrm{C} 3$ on this IgG2a-dependent phagocytosis was measured. C3-depleted serum was incapable of promoting the phagocytosis seen with fresh serum (Table 4). Similarly, blockade of bacterially bound $\mathrm{C} 3$ reduced the number of associated organisms to levels indistinguishable from those seen with this concentration of antibody alone $(0.3 \pm 0.2$ versus $0.8 \pm 0.5)$ (Table 4$)$.

The effects of MAb M1/70 and 2.4G2 on the interaction of organisms incubated with subopsonic concentrations of antibody ( $1.67 \%$ ascites fluid) and $4 \% \mathrm{Ni}-\mathrm{S}$ was measured to determine the role of CR3 and Fc receptors. Antibody M1/70 inhibited $87 \%$ of the interaction (inhibition index $=0.87 \pm 0.09, n=5$ ) and reduced the number of associated organisms to $0.5 \pm 0.4$, a level indistinguishable from background. Antibody $2.4 \mathrm{G} 2$ inhibited $41 \%$ of the interaction (inhibition index $=0.41 \pm 0.27, n=$

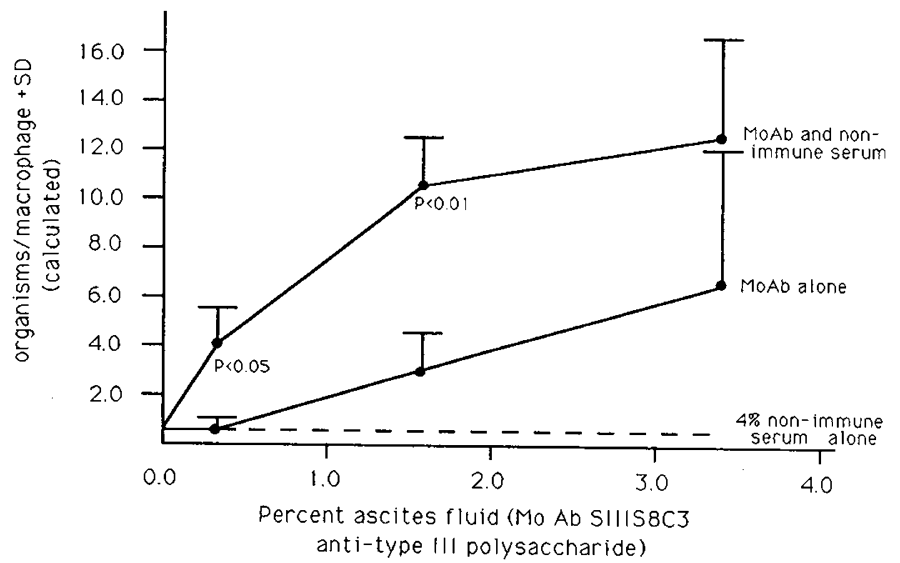

Fig. 4. Association of type III group B streptococci with macrophages in the presence of varied concentrations of murine IgG2a MAb (SIIIS8C3) alone and a constant concentration (4\%) of fresh Ni-S. Points represent organisms/macrophage $+\mathrm{SD}$ for at least three experiments. $p$ values indicate comparison of asscoiation in the presence of MAb alone with $\mathrm{MAb}$ and $4 \%$ serum as determined by $t$ test.
Table 4. Effect of 4\% Ni-S, C3-depleted 4\% Ni-S (CoVF-S), or $F\left(a b^{\prime}\right) 2$ anti-C3 fragments with $4 \% \mathrm{Ni}-\mathrm{S}$ on the interaction of type III group B streptococci with macrophages in presence of $0.33 \%$ ascites fluid containing $M A b(\operatorname{Ig} G 2 a)$ directed against type III capsule

\begin{tabular}{ccccc}
\hline & $\begin{array}{c}\text { No serum } \\
\text { (Mab } \\
\text { alone) } \\
(n=5)\end{array}$ & $\begin{array}{c}\text { Ni-S } \\
(n=5)\end{array}$ & $\begin{array}{c}\text { CoVF-S } \\
(n=3)\end{array}$ & $\begin{array}{c}4 \% \text { Ni-S and } \\
\text { F }\left(\mathrm{ab}^{\prime}\right) 2 \text { anti- } \\
(n=3)\end{array}$ \\
\hline $\begin{array}{c}\text { Organisms/ } \\
\text { macrophage* }\end{array}$ & $0.8 \pm 0.5 \dagger$ & $4.2 \pm 1.6$ & $0.4 \pm 0.3 \dagger$ & $0.3 \pm 0.2 \dagger$ \\
\hline
\end{tabular}

* Organisms/macrophage determined by radiobinding assay in the presence of IgG2a MAb and specified reagents.

$\dagger$ Differences compared to Ni-S significant $(p<0.01)$ as determined by $t$ test.

4) and reduced the number of associated organisms from $4.1 \pm$ 0.5 to $2.9 \pm 0.5(n=4)$.

\section{DISCUSSION}

In the work presented here, we have characterized the complement-dependent interaction of group B streptococci with murine macrophages and identified the importance of C 3 and CR 3 in binding and ingestion of these bacteria by mouse macrophages. We have show specifically that $l$ ) deposition of $\mathrm{C} 3$ on the surface of these organisms in both Ni-S and Im-S enhances the interaction of these organisms with resident murine macrophages; 2) this C3-dependent process, when it occurs in Ni-S, leads chiefly to binding to resident macrophages and appears mediated by the $\mathrm{CR} 3$; and 3) this C3-dependent interaction can, in the presence of subopsonic concentrations of an IgG2a antibody, be required for antibody-mediated ingestion of these bacteria.

The role of $\mathrm{C} 3$ in the binding of group B streptococci to macrophages in the presence of $\mathrm{Ni}$-S is demonstrated by the dependence of this binding on fresh serum, the absence of binding in serum obtained from C3-depleted, CoVF-treated animals, and the inhibition of this interaction with $F\left(a b^{\prime}\right) 2$ fragments of antibody against C3. Furthermore, the dependence of this interaction on C3 is suggested by complete inhibition $(95 \%)$ of this interaction with blockade of the CR3, the major macrophage surface receptor for C3bi. The lack of inhibition after blockade of Fc receptors strongly suggests that antibody does not play a role in directly mediating this interaction. In contrast, in immune serum C3-dependent mechanisms act along with Fcmediated interactions to bind and ingest these bacteria. The number of organisms associated with these cells is only partially reduced when serum is heat-inactivated in the presence of $\mathrm{F}\left(\mathrm{ab}^{\prime}\right) 2$ fragments of antibody to C3 or after CR3 blockade. Complete inhibition of this interaction is possible only after Fc receptors are blocked. Therefore, complement, specifically $\mathrm{C} 3$, is involved in the interaction of group B streptococci with macrophages not only in the presence of Ni-S, but also in the presence of serum from convalescent animals that contain relatively high concentrations of antibody.

Previous studies examining the interaction of C3-coated red cells (reviewed in reference 30) and C3-opsonized encapsulated bacteria (3) suggest that complement-mediated interactions of C3-opsonized particles with nonactivated mononuclear phagocytes result in binding without ingestion (31). Consistent with these observations, $69 \%$ of the group B streptococci that associate with resident macrophages via C3-dependent mechanisms in $\mathrm{Ni}$ $\mathrm{S}$ are bound but not ingested. Although it may be that the C3directed binding does not lead to ingestion of these bacteria, binding may be important in the chain of events leading to sequestration of bacteria by macrophages in the reticuloendothelial system and may serve as an important mechanism of clearing these bacteria from the bloodstream in the nonimmune host. In the presence of antibody, however, this binding can act to 
enhance antibody-mediated phagocytosis as suggested by our observations using Im-S. With this serum, the number of organisms that associate with macrophages is increased 6-fold and, in contrast to the interaction seen with $\mathrm{Ni}-\mathrm{S}$, the majority $(82 \%)$ of organisms is ingested. These findings are consistent with recent work examining bacterial killing by polymorphonuclear leukocytes (15). In this work, MAb against human CR 3 expressed on polymorphonuclear leukocytes decreased killing and, therefore, probably ingestion of type III group B streptococci by these phagocytes in the presence of normal or hypogammaglobulinemic serum (15). Although the fate of organisms bound or ingested by macrophages may be different from that of organisms bound or ingested by polymorphonuclear leukocytes, these observations together underscore the importance of the CR3 in determining bacteria-phagocyte interactions and suggest that opsonization of group B streptococcus with C3bi, a major ligand for the CR3, is important in determining host defense against these pathogens.

To examine how complement might enhance antibody-dependent interaction of group B streptococci with macrophages, the effect of serum on the interaction of organisms in the presence of an IgG2a MAb to type III capsule was examined. We found that concentrations of an IgG2a antibody and fresh Ni-S that are insufficient to mediate either binding or ingestion by themselves are capable of mediating interactions of organisms with macrophages when used in combination. In contrast to the interaction observed with Ni-S alone., the majority of organisms $(56 \%)$ associated with macrophages after incubation in the presence of $\mathrm{MAb}$ and Ni-S is ingested rather than merely bound. This interaction does not occur in the presence of heat-inactivated serum, in C3-depleted serum, in the presence of $F\left(a b^{\prime}\right) 2$ fragments of antibody to $\mathrm{C} 3$, or after blockade of CR3. This indicates that C3-directed interactions can be required for antibody-dependent phagocytosis, at least at low levels of antibody. This finding supports a concept proposed in recent work with polymorphonuclear leukocytes (15) that complement and Fc receptors may act synergistically in determining phagocytosis of group B streptococcus in patients with small amounts of type-specific serum antibody.

The study presented here shows that $\mathrm{C} 3$ is an important opsonin for type III group B streptococci. Complement mediates binding of type III group B streptococcus to the surface of resident murine macrophages largely via CR3 in the presence of $\mathrm{Ni}-\mathrm{S}$ and enhances bacteria-macrophage interactions in the presence of antibody. These observations, along with those recently made suggesting the importance of mononuclear phagocytes in defending against group $B$ streptococcal infection $(14,32)$, indicate that examining both opsonization of these bacteria by specific $\mathrm{C} 3$ ligands and macrophage phagocytosis of group B streptococcus via specific receptors in a human system may provide important insight into how complement influences the newborn's defense against these pathogens.

\section{REFERENCES}

2. Joiner KA, Brown EJ, Frank MM 1984 Complement and bacteria: chemistry and biology in host defense. Annu Rev Immunol 2:461-491

2. Gordon DL, Johnson GM, Hostetter MK 1986 Ligand-receptor interaction in the phagocytosis of virulent Streptococcus pneumoniae by polymorphonuclear leukocytes. J Infect Dis 154:619-626

3. Noel GJ, Mosser DM, Edelson PJ 1990 Role of complement in mouse macrophage binding of Haemophilus influenzae type b. J Clin Invest 85:208218
4. Winklestein JA, Smith MR, Shin HS 1975 The role of C3 as an opsonin in the early stages of infection. Proc Soc Exp Biol Med 149:397-401

5. Hosea SW, Brown EJ, Frank MM 1980 The critical role of complement in experimental pneumococcal sepsis. J Infect Dis 142:903-909

6. Noel GJ, Katz S, Edelson PJ 1988 Complement-mediated early clearance of Haemophilus influenzae type $\mathrm{b}$ from blood is independent of serum lytic activity. J Infect Dis 157:85-90

7. Shigeoka AO, Hall RT, Hemming VG, Allred CD, Hill HR 1978 Role of antibody and complement in opsonization of group B streptococci. Infect Immun 21:34-40

8. Hemming VG, Hall RT, Rhodes PG, Shigeoka AO, Hill HR 1976 Assessment of group $\mathrm{B}$ streptococcal opsonins in human and rabbit serum by neutrophil chemoluminescence. J Clin Invest 58:1379-1387

9. Shigeoka AO, Hall RT, Hill HR 1979 Strain specificity of opsonins for group B streptococci types II and III. Infect Immun 23:438-445

10. DeCueninck BJ, Eisenstein TK, McIntosh TS, Shockman GD, Swenson RM 1983 Quantitation of in vitro opsonic activity of human antibody induced by a vaccine consisting of the type III-specific polysaccharide of group B streptococcus. Infect Immun 39:1155-1160

11. Campbell JR, Baker CJ, Metzger TG, Edwards MS 1988 Functional activity of class-specific antibodies to type III group B streptococcus. Pediatr Res 23:31-34

12. Edwards MS, Kasper DL, Jennings HJ, Baker CJ, Nicholson-Weller A 1982 Capsular sialic acid prevents activation of the alternative complement pathway by type III group B streptococci. J Immunol 128:1278-1283

13. Edwards MS, Nicholson-Weller A, Baker CJ, Kasper DL 1980 The role of specific antibody in alternative complement pathway-mediated opsonophagocytosis of type III group B streptococcus. J Exp Med 151:1275-1287

14. Anthony BF, Concepcion NF 1989 Opsonic activity of human IgG and IgM antibody for type III group B streptococci. Pediatr Res 26:383-387

15. Smith CL, Baker CJ, Anderson DC, Edwards MS 1990 Role of complement receptors in opsonophagocytosis of group B streptococci by adult and neonatal neutrophils. J Infect Dis 162:489-495

16. Edwards MS, Buffone GJ, Fuselier PA, Weeks JL, Baker CJ 1983 Deficien classical complement pathway activity in newborn sera. Pediatr Res 17:685687

17. Mills EL, Bjorksten B, Quie PG 1979 Deficient alternative complement pathway activity in newborn sera. Pediatr Res 13:1341-1344

18. Baker CJ, Kasper DL 1976 Correlation of maternal antibody deficiency with susceptibility to neonatal group B streptococcal infection. N Engl J Med 254:753-756

19. Baechler CW, Baker CJ, Kasper DL, Fleming DM, Webb BJ, Yow MD 1979 Group B streptococcal colonization and antibody status in lower socioeconomic parturient women. Am J Obstet Gynecol 13:171-173

20. Shigeoka AO, Bathras JM, Pincus SH, Hill HR 1987 Reticuloendothelia clearance of type III group B streptococci opsonized with type III specific monoclonal antibodies of IgM or IgG2a isotypes in an experimental rat model. Pediatr Res 21:334A(abstr)

21. Ferrieri P, Burke B, Nelson J 1980 Production of bacteremia and meningitis in infant rats with group B streptococcal serotypes. Infect Immun 27:10231032

22. Noel GJ, Santos JI, Vitale JJ 1985 Newborn sepsis following antepartum group B streptococcal maternal infection in rats. Pediatr Res 19:297-299

23. Rote NS, Taylor NL, Shigeoka AO, Scott JR, Hill HR 1980 Enzyme-linked immunosorbent assay for group B streptococcal antibodies. Infect Immun 27:118-123

24. Egan ML, Pritchard DG, Dillon Jr HG, Gray BM 1983 Protection of mice from experimental infection with type III group B streptococcus using monoclonal antibodies. J Exp Med 158:1006-1011

25. Mosser DM, Edelson PJ 1985 The mouse macrophage receptor for C3bi (CR3) is a major mechanism in the phagocytosis of leishmania promastigotes. Immunol 134:3307-3310

26. Swinscow TDV 1976 Statistics at Square One. British Medical Association, London, $\mathrm{p} 86$

27. Brown EJ, Bohnsack JF, Gresham HD 1988 Mechanism of inhibition of immunoglobulin G-mediated phagocytosis by monoclonal antibodies that recognize the Mac-1 antigen. J Clin Invest 81:365-375

28. Unkeless JC 1979 Characterization of a monoclonal antibody directed agains mouse macrophage and lymphocyte Fc receptors. J Exp Med 150:580-596

29. Unkeless JC, Scigliano E, Freedman VH 1988 Structure and function of human and murine receptors for IgG. Annu Rev Immunol 6:251-281

30. Unkeless JC, Wright SD 1988 Phagocytic cells: FC and complement receptors. In: Gallin JI, Goldstein IM, Snyderman D (eds) Inflammation: Basic Principles and Clinical Correlates. Raven Press, New York, pp 343-362

31. Ehlenberger AG, Nussenzweig V 1977 The role of membrane receptors for C3b and C3d in phagocytosis. J Exp Med 145:357-371

32. Yang KD, Bohnsack JF, Hawley MM, Augustine NH, Knape WA, Egan ML Pritchard DG, Hill HR 1990 Effect of fibronectin on IgA-mediated uptake of type III group B streptococci by phagocytes. J Infect Dis 161:236-241 